\title{
Effect of Governance on the Efficiency of the Indonesian Banking Industry
}

\author{
Fransiska Novina Hayu Indrianti ${ }^{1}$ \\ Sutrisno T. ${ }^{2}$ \\ Erwin Saraswati ${ }^{3}$ \\ ${ }^{1,2,3}$ Faculty of Economics and Business, Brawijaya University, Indonesia \\ email: fransiskanovina@gmail.com
}

DOI: https://doi.org/10.24843/JIAB.2020.v15.i01.p09

\begin{tabular}{l} 
Jurnal Ilmiah Akuntansi \\
dan Bisnis \\
(JIAB) \\
\hline Volume 15 \\
Issue 1 \\
January 2020 \\
Page 90 - 104 \\
p-ISSN 2302-514X \\
e-ISSN 2303-1018 \\
\hline ARTICLE INFORMATION: \\
\hline Received: \\
09 July 2019 \\
Revised: \\
11 October 2019 \\
Accepted: \\
06 January 2020 \\
\hline
\end{tabular}

\begin{abstract}
This study aims to examine and determine the effects of corporate governance on the efficiency of the Indonesian banking sector. The research calculated DEA efficiency and performed logistic regression, with a total sample of 150 observations. Results show that independent commissioners, the educational level of commissioners, the board of commissioners meeting, and the term of office of the commissioners all have a significant impact on improving the efficiency of the banking industry. Conversely, the large number of commissioners as well as the gender do not have any effect on banking efficiency. These findings indicate that authorities should not focus on the size of the board and the gender among the board commissioners in finding ways to increase or decrease a firm's efficiency. The results of this study can contribute to academic research through agency theory and resource dependence theory as well as provide insights that can be used by practitioners.
\end{abstract}

Keywords: Governance, banking efficiency, DEA.

\section{INTRODUCTION}

Indonesia as a developing country was affected by the spread of the economic crisis that took place in the United States in 2008. The perceived impact was seen in the case of Century Bank, which was experiencing financial difficulties. Sumedi (2014) stated that Century Bank management failed to meet capital adequacy and was experiencing serious liquidity problems, thus harming many customers. Banks are the most important financial institutions and greatly affect the economy both micro and macro (Abidin, 2007). Every problem that occurs in the banking sector is able to cause a number of losses throughout the country, because banks have a function as an intermediary in the economy as a whole (Soba et al., 2016). The Indonesian Banking Statistics Report shows the performance of the banking industry has decreased, as seen from the ROA ratio of banks starting in 2012 which amounted to $3.11 \%$ which then dropped in 2013 to $3.08 \%$ and continued to decline until in 2016 reaching $2.23 \%$. Soba et al. (2016) states that if bad corporate management practices are the cause of the decline in the ability of banks to manage their liabilities and assets, so this situation causes banks to experience a liquidity crisis.

Important decision making that impacts on a company's sustainability can be analyzed from evaluating its performance, and efficient performance is the desired performance. The company's performance can be said to be efficient if the company can carry out the company's goals and costs to a minimum. Putri and Lukviarman (2008) stated that by paying attention to the efficiency of companies in dealing with competition during globalization, it is expected to be able to compete healthily and profitably. Lehmann et al. (2004) assume that companies operating at a high level of efficiency are associated with higher profitability. Measuring efficiency measures have several advantages over traditional performance indicators, so that decision making will be better with accurate results (Tanna et al., 2011). If a company is said to be inefficient, then in the future the company 
may experience financial difficulties and losses. Financial difficulties are a situation close to bankruptcy, and will have more impact on banking companies that have problems with the loss of customer confidence (Bestari \& Rohman, 2013).

Lehmann et al. (2004) assume that companies operating at a high level of efficiency are associated with higher profitability. For companies to achieve high levels of efficiency, the board must be able to oversee management in setting policies and decision making (Salim et al., 2016). The main task of the board of commissioners is to provide direction and oversee actions taken by the board of directors to be in line with the interests of shareholders, so that this observation is more centered on the board of commissioners to represent the composition of good company management. Banking company governance that is not in accordance with standards can have an impact on the occurrence of a country's crisis, so various efforts must be made so that good corporate management can be carried out as a whole (Darmadi, 2013a).

Good company management by looking at the composition of the board of commissioners in this study can explain how the company should regulate its corporate governance so that the company can continue to be efficient. In order for companies to achieve high levels of efficiency, the board of commissioners should carry out its responsibilities to recruit and oversee management in setting policies and objectives, and to make decisions in preventing excessive risk taking by management (Salim et al ., 2016). Brick et al. (2010) explains that the board of commissioners is responsible for providing strategic advice to management and the activities of the board will increase along with increased investment opportunities. The behavior of the board can differ from the wishes of the shareholders, because the board usually prioritizes its personal goals (Manzaneque et al., 2016). On the other hand, the commissioner has an important role in being able to increase the value of the company.

Study theories used are agency theory and resource dependence theory. Agency theory explains the agency relationship that is formed when the owners (principals) entrust management (agents) to manage the deposited capital and make decisions on behalf of the principal in running the company's business, while between the principal and agent have different motivations (MC Jensen and Meckling, 1976). Resource Dependence Theory explains that critical resources are needed by organizations for organizational development and become very important, so that it will influence organizational behavior (Pfeffer, 1973). Agency Theory recommends that an independent board be used for measurement in ensuring control over management (Manzaneque, et al ., 2016; Poudel and Hovey, 2013). Having an independent board reduces information asymmetry and agency costs between shareholders and management. An increase in operational supervision that avoids insider influence makes the company more efficient (Kristanti et al., 2016; Manzaneque et al ., 2016; Ombaba and Kosgei, 2017; Wang et al ., 2007).

Resource dependence theory shows that each board has different opinions, so diversity can add information shared by the board to managers (GarcíaMeca et al., 2015; Salim, et al., 2016). Gender diversity is likely to make the board have different strategic choices, so that the final decision making of the board will be maximized to improve the efficiency of the company's performance. Gender diversity in corporate governance can reduce conflict and make companies more sustainable and more risk averse (Adams and Funk, 2010).

Kristanti et al. (2016) proves that a board that has a high position must have a quality that is measured by its educational background. Each board member must have sufficient skills and expertise, thereby increasing hiso versight role (Ombaba \& Kosgei, 2017). The presence of qualified board members increases the integrity of the board in controlling and monitoring company management. The board of commissioners who have an educational background in economics and finance show their expertise in making the right decisions, so the company does not have to experience financial difficulties.

The board of commissioners has a role as supervisor of management performance, the appointment of the board of commissioners is due to agency problems such as information asymmetry. Resource dependency theory suggests that more commissioners facilitate high quality decision making (Salim, et al., 2016). The greater number of commissioners can increase the supervisory function of management and control management consumption, so that waste of resources can be avoided (Bashir \& Asad, 2018; Brédart, 2014; Manzaneque, et al ., 2016; Poudel and Hovey, 2013; 
Salim et al ., 2016; Soba et al ., 2016; Tanna et al ., 2011).

The board of commissioners' meeting is important to be held so that the board understands if the company's actions are in line with the plans that have been set. Brick \& Chidambaran (2010) state that an increase in board meetings results in improved performance, so as to be able to communicate information and make appropriate decisions to managers. The higher frequency of board meetings causes the board to carry out its duties in accordance with the expectations and interests of shareholders, and can monitor management more efficiently.

Knowledge of each individual commissioners in handling problems and knowledge will be of organizational culture can be seen from the company's long tenure in a company. The longer a person occupying the position of board of directors in a company then it will make people more aware of the specific information of the company, so the decision would be more appropriate for the company. A board that has a long term of office can better understand the culture of the company, so the board is able to propose strategies that are appropriate to the company culture and more efficiently. The increasing tenure of the board will make the company's performance better, so that the company avoids risk and makes the company more efficient (Huang, 2013; Melo, 2012). Based on the statement above, the research framework is as follows:

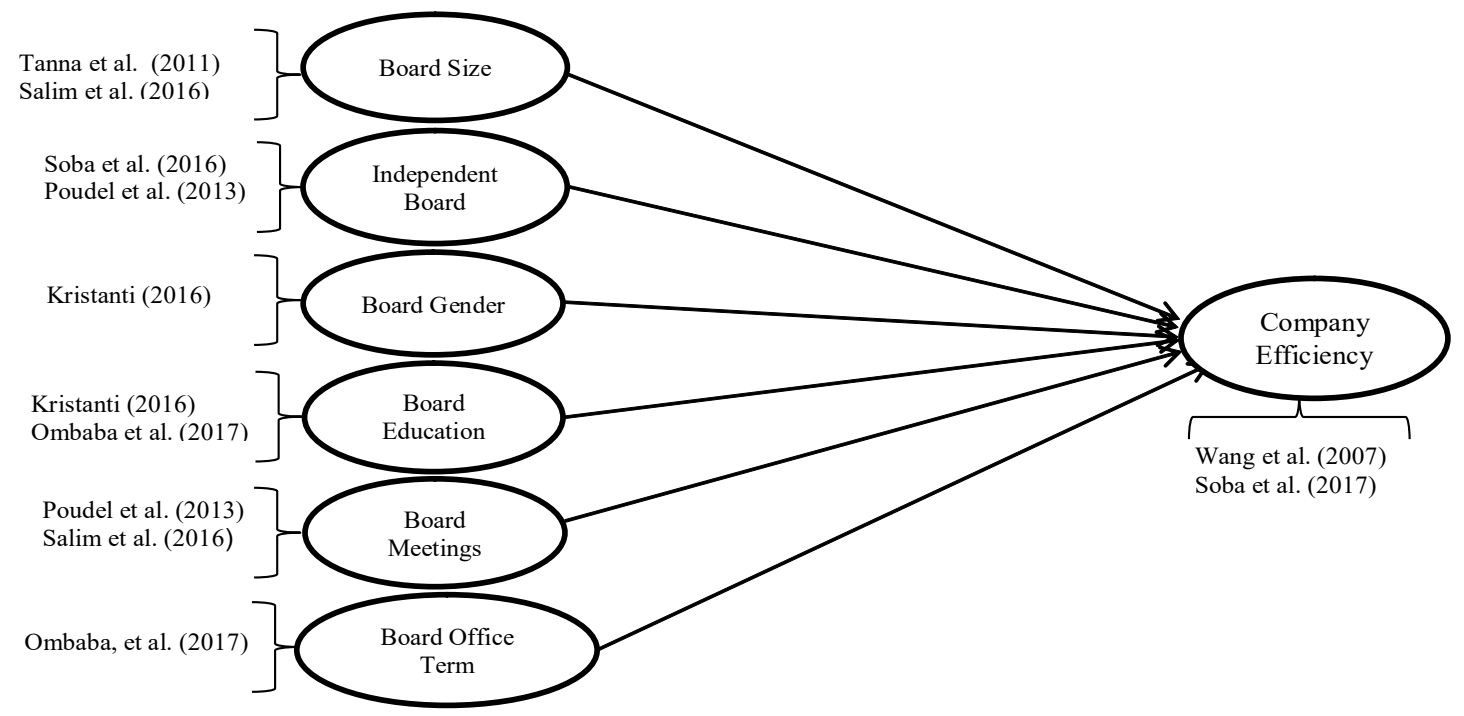

Figure 1. Research Model

Source: Processed Data, 2019

The purpose of this observation is to assess the company's internal management mechanism on banking efficiency in Indonesia in 2012-2017. This study can contribute to better academic insights about the role of corporate governance during the performance of the banking industry has decreased in 2012 to 2016, and is attractive to practitioners (managers, investors, policy managers). For this purpose, the researcher decided to conduct a logistic regression analysis on a sample of 150 companies whose data was obtained from the Indonesia Stock Exchange and the website of each company. Logistic regression analysis is carried out because this study is used so that the relationships between the dependent variables that are qualitative (binary or dichotomous) and each independent variable that is both qualitative and quantitative can be known. To process company efficiency data, the Data Envelopment Analysis (DEA) study tool is used. By using logistic regression analysis it can be possible to detect the mechanism of company management that affects company efficiency.

A large number of board members will make the board more critical in evaluating company performance. The addition of members of the board of commissioners can increase knowledge and expertise, which is useful for decision making for the creation of efficient company performance (Soba et al., 2016). Resource dependency theory suggests that large numbers of councils facilitate high- 
quality decision making (Salim et al., 2016). The large size of the members of the board of commissioners will improve the supervisory function of the board of commissioners and can control management consumption, so that waste of resources can be avoided. This statement is supported by several previous studies that found results namely board size had a positive effect on company efficiency (Bashir \& Asad, 2018; Brédart, 2014; Manzaneque, et al., 2016; Poudel and Hovey, 2013; Salim, et al., 2016; Soba et al ., 2016; Tanna et al ., 2016). $\mathrm{H}_{1}$ : The size of the board of commissioners has a positive influence on company efficiency.

Agency Theory suggests to ensure that oversight of management is carried out properly then the independence of the board is used as a measure (Manzaneque, et al ., 2016). Having an independent board reduces information asymmetry and agency costs between shareholders and management. Board independence, measured as a percentage of outside directors, can represent another important factor for effective board monitoring (Wang etal ., 2007). Previous research (Kristanti, et al ., 2016; Manzaneque, et al ., 2016; Ombaba \& Kosgei, 2017) also provided results where companies that had a large number of independent boards would increase the company's operational control, so as to prevent financial distress situations.

$\mathrm{H}_{2}$ : The proportion of independent boards has a positive influence on company efficiency.

Resource dependence theory proves that diversity can add information shared by the board to managers, because each board has different information (García-Meca et al ., 2015). The benefit of diversity is that councils with different backgrounds have different points of view. Women's councils have better values than men's councils, so they are more careful in making risky decisions and are more diligent in attending board meetings. Gender diversity can reduce conflict and make companies more sustainable and more risk averse (Adams \& Funk, 2010). The presence of women on the board increases the mechanism of corporate governance by not daring to take higher risks, resulting in companies experiencing financial difficulties getting smaller. Gender diversity has a positive impact on financial performance, which proves that the increasing number of women's councils can improve company performance. (García-
Meca, et al., 2015; Khan et al ., 2017; Kristanti, et al ., 2016; Nielsen \& Huse, 2010).

$\mathrm{H}_{3}$ : Board gender diversity has a positive effect on company efficiency.

The existence of a qualified board of commissioners increases the integrity of the board in controlling and monitoring company management. This is supported by the theory of resource dependence that a board must be equipped with adequate skills and expertise so as to increase its supervisory and supervisory role (Ombaba \& Kosgei, 2017). Some of the results of previous studies (Ahmad, 2013; Huang, 2013; Kristanti et al ., 2016) also prove that the educational background of the council on economic and financial theories has a positive effect on company efficiency, so companies can avoid bankruptcy. A qualified board will make the right decision in handling organizational problems better.

$\mathrm{H}_{4}$ : The educational background of the board has a positive influence on company efficiency.

According to Bashir \& Asad (2018) board meetings can also reduce agency costs by increasing the involvement of board members in meetings. The agency problem will diminish as the council communicates more often, so the council can exchange strategies that are right for the company. The higher frequency of board meetings can cause directors to carry out their duties in accordance with the expectations and interests of shareholders and can monitor management more efficiently (Brick \& Chidambaran, 2010).

$\mathrm{H}_{5}$ : The number of board meetings has a positive influence on company efficiency.

Resource dependency theory states that years of service are an indicator of how much knowledge and specific experience a company has in human capital (or the board), so that the board's ability to monitor and provide resources (Maere et al ., 2014). The term of office of the board must be able to increase the ability of the board to monitor and provide resources for the company, so as to reduce the risk of financial distress. The increasing tenure of the board will make the company's performance better, so that the company avoids risk and makes the company more efficient (Huang, 2013; Melo, 2012). 
$\mathrm{H}_{6}$ : The term of office of the board has a positive influence on company efficiency.

The difference between this study and previous studies is that researchers used corporate governance variables that were not included by previous researchers in their research. The researcher added the council education variable contained in the research of Kristanti et al. (2016), gender diversity variables discussed in Huang's (2013) research, as well as council tenure variables in the research of Ombaba et al. (2017) as an independent variable. The researcher considers the weaknesses of the previous research that is adding to the research period and using a sample of different types of banking companies compared to the previous research sample, so that the research results can be generalized. The researcher took the variables which proved the inconsistency of the results, as well as the variables that had not been proven to be related to the company's efficiency variables in the previous study.

\section{RESEARCH METHOD}

In accordance with its objectives, this research uses the positivism paradigm with a quantitative approach. Quantitative studies try to measure things appropriately (Cooper \& Schindler, 2017). The data in this study are included in secondary data, seen from how to obtain the data. The documents as data sources in this study are annual reports in the form of financial and non-financial data for banking companies in 2012-2017. The selection period is based on the performance of the banking industry which declined in 2012 to 2016 which then rose in 2017. The data needed in the annual report are data on the profile of the board of commissioners which includes the level of education, tenure, board gender, and the biodata of the board of commissioners. In addition, accounting data are also needed in this study in order to understand outputs and inputs in measuring the performance of company efficiency. The data is obtained from the Indonesia Stock Exchange website (www.idx.co.id) and the website of each company.

This observation was carried out in order to obtain empirical evidence regarding variables of corporate governance that can affect banking efficiency in Indonesia. The variables used in this study consist of the dependent variable and the independent variable. The dependent variable in this study is banking efficiency, while the independent variable comes from the company's management mechanism which is proxied in the variable size of commissioners, independent commissioners, gender diversity of commissioners, education of commissioners, number of commissioners' meetings, and term of office of commissioners.

The population of this observation is that all banks in the 2012-2017 study year were listed on the Indonesia Stock Exchange (IDX). Determination of population in banking companies, due to banks playing an important role in society, which has an important position in the process of driving economic growth and financial system stability (John et al ., 2018). The sampling technique in this observation uses a purposive sampling method, which is a determination based on certain conditions of the researcher. The criteria used as the basis for determining the sample are: (1) the sample is a bank listed on the IDX in the year of observation (20122017); (2) the company publishes annual reports and complete financial reports during the year of observation (2012-2017), which are obtained from the IDX website and the website of each company; (3) The company's annual report presents data on the profile of the board of commissioners and the financial data required. Based on the researchers' criteria, 150 samples were obtained that met the requirements for 6 years of observation.

Calculation of the Bank Efficiency variable used is efficiency using an intermediation approach in determining its inputs and outputs. This research uses input-oriented Data Envelopment Analysis (DEA) models, which means that each decisional unit analyzed shows minimum input so that it maintains a constant level of output. Calculation of this variable refers to the research model of Salim et al. (2016), Andrie' et al. (2018), Tanna et al. (2011), and Soba et al. (2016) include: determining input data (total deposits, interest costs, operating costs) and output data (total loans, interest income, other operating income). The calculation of these independent observational variables includes: Total Board of Commissioners (total number of commissioners), Independent Commissioners (ratio of independent commissioners), Gender of the Board of Commissioners (ratio of women to gender), Education of the Board of Commissioners (number of commissioners who have knowledge and expertise in finance), Commissioner Meeting (number of commissioners' meetings), and Commissioner Term of Service (average number of years a commissioner 
has served). For more details, here is a table of measurements of input and output on the dependent variable, and measurement of independent variables based on previous studies:

Table 1. Measurement of Research Variables

\begin{tabular}{|c|c|}
\hline $\begin{array}{c}\text { Variable Name } \\
\text { Dependent Variable }\end{array}$ & Variable Measurement \\
\hline Banking Efficiency ( EP ) & $\begin{array}{l}\text { Salim et al. (2016), Andrieș et al. (2018), Tanna et al. (2011), } \\
\text { and Soba et al. (2016) }\end{array}$ \\
\hline \multicolumn{2}{|r|}{${ }^{-1}$} \\
\hline Total Deposits & $\begin{array}{l}\text { third party funds or customer funds which can be in the form } \\
\text { of demand deposits, savings, and deposits owned by banks }\end{array}$ \\
\hline Interest expense & $\begin{array}{l}\text { deposit interest given to customers because they have } \\
\text { deposited their money in a bank }\end{array}$ \\
\hline Operational expenses & $\begin{array}{l}\text { costs other than interest costs on deposits such as personnel } \\
\text { costs and administrative costs }\end{array}$ \\
\hline \multicolumn{2}{|l|}{ The output } \\
\hline Total loan & $\begin{array}{l}\text { credit given to borrowing customers who must be paid at a } \\
\text { certain time along with the interest }\end{array}$ \\
\hline Interest income & $\begin{array}{l}\text { interest on loans given to borrowers and must be paid to the } \\
\text { bank }\end{array}$ \\
\hline $\begin{array}{l}\text { Other operating income } \\
\text { Independent Variable }\end{array}$ & income other than interest income \\
\hline $\begin{array}{l}\text { Total Commissioners } \\
\text { (TDK) }\end{array}$ & $\begin{array}{l}\text { adding up the members of the board of commissioners listed } \\
\text { in the company's annual report in the board of commissioners } \\
\text { profile chapter (Bashir and Asad, 2018; Brédart, 2014; } \\
\text { Khan, et al ., 2017; Salim, et al ., 2016; Soba, et al ., 2016; } \\
\text { Wang, et al. ., 2007) }\end{array}$ \\
\hline Independent & the percentage of commissioners from external companies \\
\hline Commissioner (DKI) & $\begin{array}{l}\text { (independent) compared to the total number of members of the } \\
\text { company's internal commissioners (Andrieș, et al ., 2018; } \\
\text { Brédart, 2014; Kristanti, et al ., 2016; Poudel and Hovey, } \\
\text { 2013; Salim, et al ., 2016; Soba, et al ., 2016; Wang, et al ., } \\
\text { 2007) }\end{array}$ \\
\hline Gender Board of & ratio of the number of women to the total number of \\
\hline Commissioners (GDK) & $\begin{array}{l}\text { management board members (Darmadi, 2013b; García- } \\
\text { Meca, et al ., 2015; Huang, 2013; Khan, et al ., 2017; } \\
\text { Kristanti, et al ., 2016) }\end{array}$ \\
\hline Board of Commissioners & the number of commissioners who have knowledge and \\
\hline Education (PDK) & $\begin{array}{l}\text { expertise in finance, which then compares it with the number } \\
\text { of boards of commissioners (Ahmad, 2013; Andries, et al ., } \\
\text { 2018; Kristanti, et al ., 2016; Ombaba and Kosgei, 2017) }\end{array}$ \\
\hline Commissioner Meeting & number of board of commissioners meetings \\
\hline (RDK) & $\begin{array}{l}\text { (Bashir and Asad, 2018; Brédart, 2014; } \\
\text { Brick and Chidambaran, 2010; Poudel and Hovey, 2013) }\end{array}$ \\
\hline Board Term (MJD) & $\begin{array}{l}\text { the average number of years of commissioners in a banking } \\
\text { company and the total number of commissioners (Melo, 2012; } \\
\text { Ombaba and Kosgei, 2017) }\end{array}$ \\
\hline
\end{tabular}

Source: Processed Data, 2019

This observation requires processing the time series data merge and cross-section study. According to Sarwono (2016) because of mixing time series and cross-sectional data, the analytical method that can be used in this observation is logistic regression analysis of panel data. Panel data produces data that is more informative, varied, and less likely to occur collinearity.

This study uses 2 stages of analysis. In the first stage, the analysis technique of this observation is to measure banking efficiency by utilizing the DEA analysis tool. The calculation of the efficiency of the banking company uses DEA software, MaxDEA. Furthermore, in the second stage of logistic regression analysis is done using the Eviews 9 analysis tool, so that it can be seen how the influence of corporate governance variables on the value of efficiency that has been obtained previously. The analysis that was also carried out was descriptive statistical analysis.

Hypothesis examination in this study was carried out using logistic regression analysis. The following 
is the logistic regression equation model that will be used in the regression model:

Model 1: $\quad$ Ln $=$ EP $=\beta_{0}+\beta_{1}$ TDK $+\beta_{2}$ DKI + $\beta_{3} \mathrm{GDK}+\beta_{4} \mathrm{PDK}+\beta_{5} \mathrm{RDK}+\beta_{6} \mathrm{MJD}$

$+\varepsilon$

Explanation:

EP : Piracy Efficiency

$\beta_{0} \quad$ : Constants

$\beta_{1-6}$ : Regression Coefficient

TDK : Total Board of Commissioners

DKI : Independent Board of Commissioners

GDK : Gender of the Board of Commissioners

PDK : Board of Commissioners Education

RDK : Board of Commissioners Meeting

MJD : Term of Office of the Board of Commissioners

$\varepsilon \quad:$ Error term

Regression models with dependent variables that have more than one explanation are also called probability models. Because the dependent variable is assessed on a nominal scale of two categories $(0$ and 1), logistic regression can be called the binary response regression model. The dependent variable of this study was measured in 2 categories (the value of 1 for the company that was said to be efficient, and the value of 0 if the company was inefficient). The logit method uses the cumulative distribution function or logistic distribution function, so it is called logistic regression. Logistic regression analysis is an analysis used to determine the relationship between dependent variables that are qualitative (binary or dichotomous) with independent variables that are qualitative or quantitative.

\section{RESULTS AND DISCUSSION}

Based on data in the annual banking report recorded on the Indonesia Stock Exchange in 20122017, the profile of the board of commissioners used for the study included total commissioners, independent commissioners, board gender, board education, board meetings, and tenure. In Table 2 we can find out the minimum (min), maximum (max), mean (mean), and standard deviation values for each variable used.

Table 2. Descriptive Statistics

\begin{tabular}{llllll}
\hline & Sample & Min & Max & $\begin{array}{l}\text { The } \\
\text { mean }\end{array}$ & Std. Deviation \\
\hline Company Efficiency (EP) & 150 & 0 & 1 & 0.96 & 0.20 \\
Total Board (TDK) & 150 & 2 & 9 & 4.61 & 1.84 \\
Independent Board (DKI) & 150 & 0 & 1 & 0.60 & 0.11 \\
Gender Board (GDK) & 150 & 0 & 0.5 & 0.16 & 0.14 \\
Education Board (PDK) & 150 & 0.2 & 4 & 1.95 & 0.65 \\
Board Meeting (RDK) & 150 & 3 & 87 & 19.24 & 15.87 \\
Term of Office (MJD) & 150 & 1 & 18 & 6.19 & 4.02 \\
Valid N (listwise ) & 150 & & & & \\
\hline
\end{tabular}

Source: Processed Data, 2019

Table 2. shows that the average value of the Company Efficiency variable (0.96) is close to the maximum number (1), this explains that the efficiency of banking companies in Indonesia is mostly at a good level. The Total Board of Commissioners variable shows an average of 4.61 , this means that banking companies are in accordance with existing regulations, where there are at least 2 commissioners. On the Independent Board of Commissioners the average value shows a value of 0,60 , which is in accordance with regulations that at least the composition of independent commissioners is $30 \%$ of the total members of the board of commissioners. The Commissioner Gender
Variable shows an average of 0,16 , compared to its maximum value of 0.5 , so it can be concluded that there are still not many female gender-paid boards in banking companies in Indonesia. On the average educational background of the board of commissioners, the economy is quite good, namely 1,95 of the maximum value of 4 , indicating half of the total board of commissioners has a level of education that is good enough to oversee the company's financial performance. For the Board of Commissioners' Meeting variable, it has a mean of 19,24 , this number indicates that the board of commissioners is in accordance with the existing provisions, which is required to be able to hold 
meetings once in 2 months. The average tenure of the Board of Commissioners is 6.19, this indicates that at least the board of commissioners has served for 1 period, which is around 5 years or until the closing of the annual GMS for 1 term of office.

Table 3. Hypothesis Testing Results (Dependent Variable: EP)

\begin{tabular}{lll}
\hline Variable & Beta & Z-statistics (Prob.) \\
\hline Constant & $-17,58314$ & 0.044 \\
TDK & 0.760799 & .1585 \\
DKI & 10,36181 & $0.0902 * * *$ \\
GDK & $-3,800665$ & 0.2801 \\
PDK & 3,897887 & $0.0328 * *$ \\
RDK & 0.415229 & $0.0428 * *$ \\
MJD & 0.290309 & $0.0928 * * *$ \\
\hline Pseudo R ${ }^{2}$ & \\
Prob (LR statistic) & 0.350810 & \\
Sample Size & $0.007098 * *$ & \\
Lihelihood log & -150 & \\
Prediction accuracy & $96 \% 35415$ & \\
\hline Note: ** significant $\mathrm{p}<0,05, * * *$ Significant $\mathrm{p}<0.1$ \\
Source: Processed Data, 2019
\end{tabular}

In Table 3. The Pseudo R2 value is 0,3508 , so it explains if the dependent variability can be explained by an independent variability of $35 \%$, while the difference of $65 \%$ is described by other variables that are not present in this study. Prob value (LR statistic) has a significant amount $<0.05$, so it can be determined that six independent variables (TDK,
DKI, GDK, PDK, RDK, MJD) together have an influence on the dependent variable (EP). The accuracy of the predictions on the model above shows $96 \%$, so it can be concluded that the model is good enough. In Table 4. the HL Statistic value is 2.8336 with a probability of significance of 0.9444 with a value of $>0.05$, indicating that the model can estimate

Table 4. Hosmer Lemeshow Test

\begin{tabular}{cc}
\hline HL Statistics & Prob. Chi-Sq \\
\hline 2,8336 & 0.9444 \\
\hline Source: Processed Data, 2019 &
\end{tabular}

the value of the research and may be declared acceptable because it is consistent with the observational data.

The first variable used by researchers is the size of the commissioner who is considered to have an influence on company efficiency. Commissioners have a role as controllers of management ability, the appointment of commissioners is caused by agency problems such as information asymmetry. The results of the study in Table 3 inform that Total Board of Commissioners (TDK) has no influence on the efficiency of banking companies listed on the IDX. The results of the study are in line with observations made by Ombaba et al. (2017) and Khan et al . (2017) which apparently does not produce interaction between board size on company performance. These results indicate that the number of commissioners is not the focus of problems in increasing or decreasing company performance. This statement is in accordance with Jensen (1993) which proves that a large number of councils are efficiently unable to monitor top management, thus causing financial difficulties. Salloum and Azoury (2010) agree that company performance is highly dependent on the size of the board, and a larger board can hamper coordination. By hampering coordination, the board is prohibited from participating in strategic decision making thereby reducing the role of supervision. Ombaba and Kosgei (2017) explained that no influence was found which was likely to occur because the council was prohibited from participating in decision making. At that time the commissioner does not have a role as supervisor of management performance.

The research results of the Total Board of Commissioners variable reject the statement that the increasing number of commissioners can increase the commissioner's control function towards 
management and be able to control the waste of resources by management (Bashir \& Asad, 2018; Brédart, 2014; Manzaneque, et al ., 2016; Poudel \& Hovey, 2013; Salim et al ., 2016; Soba et al ., 2016; Tanna et al ., 2011). These observations also reject previous research statements, where councils with large size actually make communication and coordination among members difficult, thus raising agency problems (Bodroastuti, 2009; MC Jensen \& Meckling, 1976; Wang et al ., 2007). Resource dependence theory which states that the large number of councils is able to facilitate high quality decision making, can also be refuted. A larger board may not necessarily make the board more critical in evaluating company performance. Large size boards actually make communication and coordination among members difficult, so supervision does not affect performance evaluation. This situation indicates that the number of commissioners is not the focus of problems in increasing or decreasing banking performance.

The second variable that is thought to have an influence on company efficiency is the proportion of independent directors. A board can be said to be independent if the board is free from management and does not have a relationship that is able to interfere with independent judgment (Ombaba \& Kosgei, 2017). The proportion of board independence is very important to monitor managers efficiently and minimize agency costs (Poudel \& Hovey, 2013). An independent board will be more fair in evaluating the company's performance without being influenced by people in the company, so that it is more trusted by shareholders. The results of the study in Table 3 suggest that the Independent Board of Commissioners (DKI) has a significant influence on banking efficiency listed on the IDX. An independent board will be better at implementing its oversight and advisory functions efficiently than the company's internal board, because the independent board is free from certain relationships or contracts. The results of the study are comparable to the observations of Wang et al. (2007) who found an increase in the proportion of independent directors resulting in a positive influence on allocation performance and cost efficiency. Previous studies (Kristanti et al ., 2016; Manzaneque et al ., 2016; Ombaba \& Kosgei, 2017) also provided results where companies with a high independent board composition could improve the control of the company's operations, thereby being able to prevent situations of financial difficulties. This is consistent with agency theory, namely that an independent board provides better control over management. The existence of an independent board is concluded can reduce information asymmetry and agency costs between shareholders and management.

The research results of the Independent Board of Commissioners variable reject the research results of Soba et al. (2016) which shows the independent board has a negative impact on bank efficiency. His research decision actually shows that companies prefer a board that can be controlled by people in the company, because important data is only owned by internal company people. However, an independent board that is fairer in evaluating company performance without being influenced by people in the company is actually more trusted by shareholders because it is able to grow the company's efficiency. The results of this observation also reject the decision of previous observations (Brédart 2014; Brick and Chidambaran, 2010; Poudel and Hovey, 2013; Salim et al ., 2016) who did not get any influence between an independent board and company efficiency. The research precisely indicates that independent board members do not contribute to management oversight because of the lack of time to exchange information with other board members or management. An independent board actually makes a meaningful contribution to the oversight function of the company, because the independent board has critical thinking and is free from certain relationships.

The third variable that is considered to have an influence on company efficiency is board gender diversity. Gender diversity was identified as a percentage of women in the size of the council (Kristanti et al ., 2016). The results of the study in Table 3 show that the Gender of the Board of Commissioners (GDK) has no influence on the banking efficiency listed on the IDX. The board of commissioners with the majority of women having gender does not have any difference from the board of men having gender, in terms of the quality of decision making. The diversity of the board's gender does not affect the efficiency of the company, possibly also due to other factors that influence. Board gender diversity does not relate to company efficiency because board position is only seen based on family relations factors for decision making and supervision, compared to expertise and 
work experience possessed (Darmadi, 2013b; Rose, 2007). That is because the majority of women cannot express opinions or acknowledge ignorance about the company's financial problems. Board gender diversity proves that boards with different points of view do not have uses or are associated with increasing or decreasing company efficiency.

The results of the Board of Commissioners' Gender variable research are different compared to observations from Adams \& Funk (2010) and Huang (2013) which actually proves that women's councils are more at risk than men's councils, because there are other factors that might influence risk-making decisions for companies that are not based on background behind the board's gender. The women's council is not certain whether it has better values than the men's council, so it is more vigilant when making risky decisions and is more diligent in attending board meetings. This provides evidence that the greater diversity of council gender types is not yet clear whether it increases conflict between councils. The results of the study refute the results from previous studies (García-Meca et al ., 2015; Khan et al ., 2017; Kristanti et al ., 2016; Nielsen \& Huse, 2010), that gender diversity has a positive impact on financial performance. This can reject the theory of resource dependency which explains that diversity can add information conveyed by the board to managers, because each board has different information (García-Meca et al ., 2015). The women's council does not necessarily have unique and different information compared to the men's council, this possibility is difficult to know because the women's council does not dare to argue when the issues discussed at the council meeting differ from the personal values they have. Women's councils tend to follow the results of the majority of decision-making, although there is critical thinking about the problems faced.

The fourth variable considered to have an influence on company efficiency is the board's educational background. High-level executives at companies that have the responsibility to provide leadership direction, must have self-quality measured from their formal educational background (Kristanti et al ., 2016). Inefficient operational condition and structure of a company due to the inability of the board to manage the company's finances, can be measured from the board's educational background. The results of the study in Table 3. show that the Education of the Board of
Commissioners (PDK) has a significant influence on the banking efficiency recorded on the IDX. This observation proves that a quality board viewed from economic and financial education has the ability to provide direction for company problems so as to increase company efficiency for the better, and be able to prevent any losses (Huang, 2013; Kristanti et al., 2016). Having a qualified board member increases the integrity of the board in controlling and monitoring management. This is in accordance with some of the results of previous studies (Ahmad, 2013; Huang, 2013; Kristanti et al ., 2016) which explain that the educational background of the board of commissioners has a positive influence on company efficiency, so companies can avoid bankruptcy.

The results of the Board of Commissioners Education variable research are in accordance with the resource dependence theory which states that a board must have sufficient skills and expertise so as to increase its supervisory role. A qualified board will make the right decisions in handling organizational problems that are more qualified and increase the credibility of the board in controlling and monitoring company management. Appropriate decisions will produce good performance and the company does not have to experience financial difficulties. The degree of economic degree held by the board will give board members financial skills that help in completing work, so as to improve the performance of the company.

The research results of the Board of Commissioners' Education variables differ from the results of a study by Darmadi (2013a) which actually shows that the level of financial ability of board members has a negative relationship on company performance. The influence is caused by the financial capacity of the board can be useful to oversee the performance of the company and solve problems of financial difficulties that occur. The research results of the Board of Commissioners' Education variables also contradict the results of research by Rose (2007) and Ombaba et al. (2017) which proves that the education of board members does not affect company performance. On the contrary, the results of the study explain that the work carried out by company boards requires a specific educational basis, especially on economic or financial aspects. Long experience in various managerial positions actually looks at the educational background, so that it can provide a board of financial expertise that helps in carrying out company operations. 
The fifth variable that is considered to have an influence on company efficiency is the number of commissioners' meetings. Board of Commissioners' meeting has the function as a company evaluation tool, so that the commissioner can make decisions according to the company's situation. The results of the study in Table 3. prove that the Board of Commissioners' Meeting (RDK) has a significant influence on the efficiency of banking companies listed on the IDX. This acquisition shows that control will be more effective with more frequent board meetings, and company efficiency will increase. Regular board meetings function so that the board gets information and knowledge about the relevant performance of the company and directs appropriate actions to address the company's problems. This is in accordance with the study of Brick et al. (2010) which revealed that an increase in commissioner meetings led to improved performance, so as to be able to communicate information and take appropriate considerations to be given to managers.

Frequent board meetings can add information, so as to make the right decision for managers. The higher frequency of board meetings causes the board to be able to carry out its duties in accordance with the wishes and interests of shareholders, and can monitor management more efficiently. Amore diligent board will be more concerned, so as to be able to devote more time to the oversight of the activities of managers to achieve shareholder expectations. The board has the role of advisor and conveys advice that can increase the value of investment opportunities for companies (Brick and Chidambaran, 2010). Increasing board meetings leads to improved performance, so as to be able to communicate information and make appropriate decisions to managers. The agency problem will diminish as the council communicates more often, so the council can exchange strategies that are right for the company. The higher frequency of board meetings can cause directors to carry out their duties in accordance with the expectations and interests of shareholders and can monitor management more efficiently (Brick \& Chidambaran, 2010).

The results of the Board of Commissioners' meeting variable differ from observational decisions from Poudel \& Hovey (2013) which prove that the lower frequency of board meetings has an influence to improve efficiency at Nepal banks. The difference in results is due to the banking companies in
Indonesia board members have enough time to meet with other boards, so that the board can increase its effectiveness. The results also reject the statements of several previous studies (Bashir and Asad, 2018; Brédart, 2014; Salim, et al ., 2016) which showed the commissioners' meeting had no relationship to company performance. The results of the study precisely explained that board meetings conducted regularly can improve company efficiency, because communication and coordination of the board is increasingly well established.

The sixth variable which is considered influential on company efficiency is the term of office of the board. The term of office of the board has an internal role of organizational culture that represents the stakeholders' trust (Melo, 2012). The observations in Table 3. explain that the Commissioner Term (MJD) has a significant effect on the efficiency of the banks listed on the IDX. These observations tell us that the long term of office of the commissioner is able to increase the likelihood of the company becoming more efficient (Huang, 2013; Melo, 2012). The longer a person occupies the position of commissioner in a company will cause the person to know more company specific information, so that decision making will be more appropriate for the company. A board that has a long term of office has special knowledge about the company, so that it can help board members to deal effectively with problems and improve the ability of the board to provide resources to the company.

Board control over corporate culture shows that be will increase as the average tenure increases. The term of office of the director must be able to increase the ability of the board when monitoring and providing resources for the company, so as to reduce the risk of financial difficulties. The board is able to propose strategies that are appropriate to the company culture and are more efficient because the board has a long term of office, so that it can better understand the company culture. A board with a long term of office has special knowledge about the company, so that it can help board members to deal effectively with problems and increase the ability of the board to provide resources to the company.

The research results of the Board of Commissioners variable tenure contradicts the observations of Ombaba \& Kosgei (2017) who argue that the long term of office of the commissioner is associated with loyalty to management. The results of the study proved that the council with a long tenure 
with the manager is able to monitor both the company and is not affected will be their special relationship. Therefore, these results imply that the longer term of office of the commissioner does not eliminate the objectivity of the board in overseeing. A board that has a long term in a company also understands the culture of the company better, so that the board can propose strategies that are appropriate to the company culture and more efficiently.

\section{CONCLUSION}

The purpose of this test is to assess how the internal corporate governance mechanism on banking efficiency in Indonesia in 2012-2017. Researchers conducted a logistic regression analysis on a sample of 150 companies whose data was obtained from the IDX and the website of each company. The logistic regression analysis of this sample will make it possible to detect the mechanisms of corporate management that affect banking efficiency.

The results of the study stated that Total Board of Commissioners has no influence on banking efficiency listed on the IDX. The acquisition of these observations indicates that no results were formed because the council was prohibited from participating in strategic decision making, as found by Ombaba et al. (2017) and Khan et al . (2017). Observations show that the Gender of the Board of Commissioners has no influence on the efficiency of banking companies listed on the IDX. That is because women cannot express their opinions and cannot contribute to the development of the company, according to the results of Darmadi's study (2013b) and Rose (2007). The observations explained that the Independent Commissioner had a significant influence on banking efficiency listed on the IDX. Companies with a high proportion of independent directors will increase the company's operating observations, thereby providing better control over management. The results showed the Board of Commissioners' Education had a significant influence on the efficiency of the banks listed on the IDX. The quality of the board seen from its education has a strong influence to improve the company's efficiency performance for the better. Observation results prove that the Board of Commissioners' Meeting has a significant effect on the efficiency of banking companies listed on the IDX. This shows that control will be more effective with more frequent board meetings, and company efficiency will increase. The observations revealed that the Board of Commissioners' Tenure has a significant effect on the efficiency of the banks listed on the IDX. The longer someone occupies the position of the board of commissioners will make the board make decisions that are more appropriate for the company.

This study contributes to the literature because this study uses corporate governance variables that were not included by previous researchers in the study. This study provides additional information for council education variables, gender diversity and board tenure as additional independent variables used. In addition, this observation also adds to the research period, so the results can be used for planning banking efficiency going forward. For investors, managers, and policy managers, this study shows that the characteristics of the board influence the likelihood of company efficiency levels. This research clearly shows that companies need to pay attention to the independent level of the board, the educational background of the council on finance and economics, the number of council meetings held to see co-ordination of the council, and the length of the board term. This research can help shareholders provide appropriate standards for quality management mechanisms, so as to grow company performance. Policy managers can use the results of these observations to provide good standards in company management. The observations can be used to improve existing policies, which are related to the Financial Services Authority Regulation (POJK) No 33 / POJK.04 / 2014 regarding Directors and Board of Commissioners of Issuers or Public Companies.

There are several limitations in this study. First, the commissioner profile data in the annual report has a different format for each company, especially for board education data. Further research can use more detailed information on the board of commissioners' training that was followed in the current year, as consideration of the board's education. Secondly, there are some translation of the board of commissioner's education which is incomplete in the company commissioner profile data, which only mentions the name of the university without majoring in education. In this research, if it does not include the education majors taken, it will be judged not from the financial sector, even though there may be more complete information about the profile of the board of commissioners. Further research may seek data sources other that can 
complement educational data commissioners. Third, the selection of the variable evaluation of the board of commissioners meeting is calculated from the total number of board meetings and joint meetings attended by the board of commissioners. The next research can use the number of internal meetings of the board of commissioners, so that the research is more focused on the internal board of commissioners.

\section{REFERENCES}

Abidin, Z. (2007, 21-22 Agustus 2007). Kinerja Efisiensi pada Bank Umum. Paper presented at the Proceeding PESAT, Auditorium Kampus Gunadarma.

Adams, R. B., \& Funk, P. (2010). Beyond the glass ceiling: Does gender matter? Management Science, 58(2), 219-235.

Ahmad, G. N. (2013). Analysis of Financial Distress in Indonesian Stock Exchange. Review of Integrative Business \& Economics Research 2(2), 521-533.

Andrie', A. M., Căpraru, B., \& Nistor, S. (2018). Corporate governance and efficiency in banking: evidence from emerging economies. Applied Economics, 50(34), 1-21.

Azoury, N., \& Salloum, C. (2010). Governance, Stress Financier et Performance des entreprises, cas du Liban, La Revue des Sciences de Gestion. Int. J. Business Performance Management 3(1), 243-244.

Bashir, A., \& Asad, M. (2018). Moderating Effect of Leverage on the Relationship between Board Size, Board Meetings and Performance: A Study on Textile Sector of Pakistan. American Scientific Research Journal for Engineering, Technology, and Sciences (ASRJETS), 39(1), 19-29.

Bestari, A. R., \& Rohman, A. (2013). Pengaruh Rasio CAMEL dan Ukuran Bank terhadap Prediksi Kondisi Bermasalah pada Sektor Perbankan. Diponegoro Journal of Accounting, 2(3), 19.

Bodroastuti, T. (2009). Pengaruh Struktur Corporate Governance terhadap Financial Distress. Ilmu Ekonomi ASET, 11(2), 1-15.

Brédart, X. (2014). Financial Distress and Corporate Governance: The Impact of Board Configuration. International Business Research, 7(3), 72-80.
Brick, I. E., \& Chidambaran, N. K. (2010). Board meetings, committee structure, and firm value. Journal of Corporate Finance, 16(4), 533553.

Cooper, D. R., \& Schindler, P. S. (2017). Metode Penelitian Bisnis. Jakarta: Salemba Empat.

Darmadi, S. (2013a). Board members' education and firm performance: evidence from a developing economy. International Journal of Commerce and Management, 23(2), 113-135.

Darmadi, S. (2013b). Do women in top management affect firm performance? Evidence from Indonesia. Corporate Governance: The international journal of business in society, 13(3), 288-304.

García-Meca, E., García-Sánchez, I.-M., \& Martínez-Ferrero, J. (2015). Board diversity and its effects on bank performance: An international analysis. Journal of Banking \& Finance, 53, 202-214.

Huang, S. K. (2013). The Impact of CEO Characteristics on Corporate Sustainable Development. Corporate Social Responsibility and Environmental Management, 20(234244).

Jensen, C. M. (1993). The Modern Industrial Revolution, Exit and the Failure of Internal Control Systems. The Journal of Finance, 48(3), 831-880.

Jensen, M. C., \& Meckling, W. H. (1976). Theory of The Firm: Managerial Behavious, Agency Costs and Ownership Structure. Journal of Financial Economics 3, 305-360.

John, A. T., Ogechukwu, O. L., \& Awolowo, O. (2018). Corporate Governance and Financial Distress in the Banking Industry: Nigerian Experience. Journal of Economics and Behavioral Studies 10(1), 182-193.

Khan, H., Hassan, R., \& Marimuthu, M. (2017). Diversity on Corporate Boards and Firm Performance: An Empirical Evidence from Malaysia. American Journal of Social Sciences and Humanities, 2(1), 1-8.

Kristanti, F. T., Rahayu, S., \& Huda, A. N. (2016). The Determinant of Financial Distress on Indonesian Family Firm. Social and Behavioral Sciences 219, 440-447.

Lehmann, E., Warning, S., \& Weigand, J. (2004). Governance Structure, Multidimensional 
Efficiency and Firm Profitability. Journal of Management and Governance 8, 279-304.

Maere, J. D., Jorissen, A., \& Uhlaner, L. M. (2014). Board Capital and the Downward Spiral: Antecedents of Bankruptcy in a Sample of Unlisted Firms. Corporate Governance: An International Review, 22(5), 387-407.

Manzaneque, M., Priego, A. M., \& Merino, E. (2016). Corporate governance effect on financial distress likelihood: Evidence from Spain. Spanish Accounting Review 19(1), 111121.

Melo, T. (2012). Determinants of corporate social performance: the influence of organizational culture, management tenure and financial performance. Social Responsibility Journal, $8(1), 33-47$.

Nielsen, S., \& Huse, M. (2010). Women directors' contribution to board decision-making and strategic involvement: The role of equality perception. European Management Review, 7(1), 16-29.

Ombaba, K. M. B., \& Kosgei, D. (2017). Board Composition and Financial Distress of Listed Firms in Kenya. An Empirical Analysis. Journal of Finance and Investment Analysis, 6(4), 75-93.

Pfeffer, J. (1973). Size, Composition, and Function of Hospital Boards of Directors: A Study of Organization-Environment Linkage. Administrative Science Quarterly, 18(3), 349-364.

Poudel, R. P. S., \& Hovey, M. (2013). Corporate Governance and Efficiency in Nepalese Commercial Banks. International Review of Business Research Papers 9(4), 53-64.

Putri, V. R., \& Lukviarman, N. (2008). Pengukuran Kinerja Bank Komersial dengan Pendekatan
Efisiensi: Studi terhadap Perbankan Go-Public di Indonesia. JAAI, 12(1), 37-52.

Rose, C. (2007). Does female board representation influence firm performance? The Danish evidence. Corporate Governance: An International Review, 15(2), 404-413.

Salim, R., Arjomandi, A., \& Seufert, J. H. (2016). Does corporate governance affect Australian banks' performance? Journal of International Financial Markets, Institutions and Money, 43, 113-125.

Sarwono, J. (2016). Prosedur-prosedur Analisis Populer Aplikasi Riset Skripsi dan Thesis dengan Eviews. Yogyakarta: Penerbit Gava Media.

Soba, M., Erem, I., \& Ceylan, F. (2016). The Impact of Corporate Governance Practices on Bank Efficiency: A Case of Turkey Journal of Süleyman Demirel University Institute of Social Sciences 3(25), 305-322.

Sumedi, D. P. (2014). OJK Berharap Kasus Bank Mutiara Tak Terulang. Retrieved 26/4, 2018, from (Online) https://bisnis.tempo.co/read/ 542626/ojk-berharap-kasus-bank-mutiara-takterulang

Tanna, S., Pasiouras, F., \& Nnadi, M. (2011). The effect of board size and composition on the efficiency of UK banks. International Journal of the Economics of Business, 18(3), 441-462.

Wang, J. L., Jeng, V., \& Peng, J. L. (2007). The Impact of Corporate Governance Structure on the Efficiency Performance of Insurance Companies in Taiwan. The Geneva Papers, 32, 264-282. 